\title{
A Incomunicação Nas Empresas De Call Centers
}

\author{
Ana Paula Gomes Vasconcelos 1
}

\section{Resumo}

Esta investigação tem como objetivo analisar como empresas de call center dialogam com seu público, considerando, dentro desse universo, os clientes. Os trabalhadores desse segmento empresarial têm de seguir um roteiro para conversar com os clientes pelo telefone, um dos aspectos que determinam, em vez da comunicação, a incomunicação. Considera-se o roteiro uma imagem, na concepção de Norval Baitello Junior. Ao utilizá-lo, observa-se que o operador de call center se conecta ao consumidor, pelo telefone, mas não há criação de vínculo entre ambos. A empresa, visando ao lucro, tenta atender minimamente o que a legislação do setor exige e proporciona um ambiente de trabalho que prejudica a comunicação fluida e natural. Essa dinâmica é analisada por meio do conceito de trabalho como vida, de Dietmar Kamper, pelos estudos de psicopatologia do trabalho, de Christophe Dejours, a partir da noção de vigilância em Michel Foucault e pela investigação de Norval Baitello Junior sobre como o fato de permanecer sentado a maior parte do tempo afeta o corpo e a mente do homem. Constatou-se que muitos trabalhadores sofrem com a repetição constante do roteiro, tanto física como psicologicamente, e alguns deles sentem-se desmotivados e incapacitados de se comunicar normalmente em sua vida fora do trabalho. Trata-se de um recorte que faz parte do conjunto de dinâmicas do mundo atual, analisado pela Teoria da Mídia, pensada por Harry Pross e Vilém Flusser. A falta da criação de vínculos entre as pessoas próximas, a sociedade acelerada em cidades carentes de tempo e espaço para todos, empresas que ratificam esse modo de vida, importando-se menos com as pessoas e mais com a lucratividade, são fatores que contribuem com a condição de incomunicabilidade na sociedade em geral e, segundo avaliação deste estudo, entre trabalhadores e clientes dos call centers.

Palavras-chave: cultura, trabalho, call center, comunicação e incomunicação.

\section{Abstract}

This study intends to analyze how call center companies dialogue with their public, considering, within that universe, customers. Workers in this business sector have to follow a script to talk to customers over the phone, one of the aspects that determine, rather than communication, incommunication. In the conception of Norval Baitello Junior, the script is considered an image. It is observed that, by using it, the call center operator connects to the consumer over the phone, but there is no creation of bonds between them. The company, aiming profit, tries to minimally comply with what the legislation of the sector requires and provides a working environment that impairs fluid and natural communication. This dynamics is analyzed through the concept of work as life, of Dietmar

\footnotetext{
${ }^{1}$ É mestre em comunicação e semiótica pela PUSSP. Pós-graduação em Comunicação Organizacional e Relações Públicas pela Faculdade Cásper Líbero, e graduada em Comunicação Social com ênfase em Jornalismo pela Universidade Presbiteriana Mackenzie. Comunica em Inglês avançado, Francês intermediário e Espanhol básico. É a atual Analista de Comunicação na Helicópteros do Brasil S.A.-Helibras.
} 
Kamper; by the studies of psychopathology of work, of Christophe Dejours; from the notion of surveillance in Michel Foucault; and by the research of Norval Baitello Junior on how the fact of remaining seated most of the time affects the buman body and mind. It was found that many workers suffer, both physically and psychologically, with the constant repetition of the script, and some of them feel unmotivated and incapable of communicating normally in their lives outside of work. It is a cut that is part of the set of today's world dynamics, analyzed by the Theory of the Media, conceived by Harry Pross and Vilém Flusser. The lack of creation of bonds between close people, the accelerated society in cities lacking time and space for all, companies that ratify this way of life, caring less about people and more about profit, are factors that contribute to the condition of incommunicability in society in general and, according to the evaluation of this study, between workers and costumers of call centers.

Key-words: culture, work, call center, communication and incommunication.

\section{Introdução}

Esta investigação visa analisar como empresas de call center dialogam com seu público, considerando, dentro desse universo, os clientes. Os trabalhadores desse segmento empresarial têm de seguir um roteiro, mais conhecido no meio como script, para conversar com os clientes pelo telefone, um dos aspectos que determinam, em vez da comunicação, a incomunicação. Considera-se o roteiro uma imagem, na concepção de Norval Baitello Junior. Ao utilizá-lo, observa-se que o operador de call center se conecta ao consumidor, pelo telefone, mas não há criação de vínculo entre ambos.

A empresa, visando ao lucro, tenta atender minimamente o que a legislação do setor exige e proporciona um ambiente de trabalho que prejudica a comunicação fluida e natural. Essa dinâmica é analisada por meio dos estudos de psicopatologia do trabalho, de Christophe Dejours, a partir da noção de vigilância em Michel Foucault e pela investigação de Norval Baitello Junior sobre como o fato de permanecer sentado a maior parte do tempo afeta o corpo e a mente do homem. Constatou-se que muitos trabalhadores sofrem com a repetição constante do roteiro, tanto física como psicologicamente, e alguns deles sentem-se desmotivados e incapacitados de se comunicar normalmente em sua vida fora do trabalho. Trata-se de um recorte que faz parte do conjunto de dinâmicas do mundo atual, analisado pela Teoria da Mídia desenvolvida por Harry Pross e Vilém Flusser.

A falta da criação de vínculos entre as pessoas próximas, a sociedade acelerada em cidades carentes de tempo e espaço para todos, empresas que ratificam esse modo de vida, importando-se menos com as pessoas e mais com a lucratividade, são fatores que contribuem com a condição de incomunicabilidade na sociedade em geral e, segundo avaliação deste estudo, entre trabalhadores e clientes dos call centers.

Um fenômeno de conexão emerge na prática da conversa telefônica entre $\mathrm{o}$ operador de call center e o consumidor. As empresas de call center, que chegaram ao país no início dos anos 90, são cada vez mais numerosas. Elas adotam padrões de atendimento que foram estudados com a finalidade de compreender os efeitos do ambiente de trabalho desfavorável e do serviço insatisfatório aos clientes.

O sofrimento físico e psíquico dos trabalhadores fica evidente nesse cenário. Afinal, as companhias adotam diversos tipos de limitações e pressões, levando o trabalhador a ter de respeitar uma disciplina 
rígida e hierarquias repressoras. Até a forma como os operadores lidam com $\mathrm{O}$ interlocutor é controlada, e dessa maneira o diálogo que irão estabelecer com o cliente é um diálogo pré-determinado. Para tanto, a empresa impõe o uso do script, ou seja, um roteiro pronto para ser falado na conversa telefônica entre o operador e o cliente.

Considera-se o script uma imagem de diálogo, já que o diálogo original só pode ser dado naturalmente, no decorrer da conversa. O script, assim como uma imagem, torna-se a presença de uma ausência ou o seu contrário, a ausência de uma presença. E, assim, como as imagens, ele é reproduzido em série pelas empresas, que tentam padronizar uma conversa que depende justamente do oposto para ser plena, afinal, o estabelecimento da comunicação se dá por meio da vinculação com o outro, do ato de ouvi-lo e a partir dessa ação elaborar uma resposta, e assim construir a "ponte" que levará à interação com o outro.

Esse mecanismo das empresas de call center, bem como a obrigatoriedade de condutas rígidas aos operadores criam nelas mesmas um ambiente de "loucura corporativa". O trabalho toma conta da vida das pessoas envolvidas que, mesmo após o expediente, dão sinais dos efeitos causados pela forma como o trabalho é organizado, apresentando quadros de ansiedade, estresse, neuroses e outras psicopatologias. Assim, as empresas mantêm os indivíduos domesticados e produzindo em ritmo acelerado, com a intenção de obter mais lucratividade.

É nesse ambiente também que surge a incomunicação, que se manifesta por meio de excessos, principalmente os relacionados à ordem e ao tempo. Incomunicação e comunicação estão presentes no mesmo tempo e no mesmo espaço. Mas, mesmo quando a comunicação é impedida e a incomunicação se torna predominante, ainda assim, a comunicação acontece por meio de alternativas. Por isso, percebe-se a tentativa de os operadores criarem vínculos com os consumidores, desviando do script a eles imposto ou estabelecendo com colegas comunicações por outros sentidos, como o da visão, ao fazer gestos e sinais.

A partir de 1880, quando um fabricante de doces utilizou o telefone para oferecer seus produtos a potenciais clientes (MANCINI, 2006, p.12), essa prática começou a se tornar cada vez mais comum entre empresas, para se comunicarem com seus clientes. No Brasil, com a chegada das multinacionais ao país nos anos de 1990, chega também esse tipo de serviço, que se desenvolve cada vez mais a partir da liberalização do setor de telecomunicações no país, entre 1997 e 1998.

Considera-se telemarketing ativo quando a empresa é quem procura o consumidor, por meio de ligação do operador de call center. Segundo Lima, tratase do formato mais antigo e usado principalmente para vender produtos $\mathrm{e}$ serviços, cobrar pagamentos não realizados, fazer pesquisa de mercado e opinião (2007, p. 20). Já o telemarketing receptivo se dá quando o público (consumidor ou interessado em adquirir o serviço) telefona para a empresa a fim de buscar alguma informação ou solicitar um serviço. Como exemplos deste tipo podem ser citados os SACs - Serviços de Atendimento ao Cliente, as linhas 0800 , e os serviços de delivery.

As empresas de call center podem ser próprias ou terceirizadas. As empresas terceirizadas são especializadas no setor, contratadas para prestar esse serviço por meio do princípio da terceirização. Já os call centers próprios se encontram inseridos numa organização de maior porte que, por opção, prefere assumir esse setor dentro de sua estrutura em vez de terceirizá-lo (SILVA, 2007, p. 37). Segundo Silva, os call centers contam com estruturas achatadas e a distribuição de gerentes, supervisores e atendentes fica na média de um gerente para 
20 supervisores e um supervisor para 20 atendentes (2007, p. 40).

\section{Call center, uma mídia terciária}

De acordo com a teoria desenvolvida pelo cientista político, escritor, jornalista e comunicólogo alemão Harry Pross, existem três tipos de mídia: a primária, a secundária e a terciária. De acordo com Pross, toda comunicação humana começa no corpo e termina no corpo. Dessa forma, ele afirma que toda "comunicação humana começa na mídia primária, na qual os participantes individuais se encontrem cara a cara e imediatamente presentes com seu corpo; toda comunicação humana retornará a este ponto" (PROSS, 1972, p. 127-8 apud BAITELLO JUNIOR, 2005, p. 80). Toda a expressão corporal faz parte da mídia primária, e naturalmente a comunicação verbal está aí incluída.

Fazem parte da mídia secundária os meios de comunicação que "transportam a mensagem ao receptor, sem que esse necessite um aparato para captar seu significado" (PROSS, 1972, p. 128 apud BAITELLO JUNIOR, 2005, p. 81). Como exemplos, a escrita, a fotografia e o jornal. Portanto, nessa categorização de mídia, somente o emissor precisará ter um aparato para se comunicar (BAITELLO JUNIOR, 2005, p. 81).

Já a mídia terciária é aquela na qual tanto emissor quanto receptor precisam estar munidos de aparatos para que ocorra a comunicação. Podem ser considerados mídia terciária a telefonia, o cinema, a televisão (PROSS, 1972, p. 226 apud BAITELLO JUNIOR, 2005, p. 82). Conclui-se, dessa maneira, que a forma de comunicação utilizada nos call centers apresenta um modelo condizente ao conceito de mídia terciária.
A emergência de uma mídia não exclui a existência da outra, elas transitam concomitantemente no processo comunicativo. A grande crítica de Baitello Junior é dirigida à evidente hipertrofia dos sistemas de mediação mais complexos (mídia terciária) acompanhada da atrofia dos sistemas primários simples $(2005$, p. 82). Há, segundo ele, "um certo ofuscamento da capacidade crítica diante da natureza mágica dos novos e vertiginosos desdobramentos da mídia elétrica" (2005, p.82). Além disso, o pesquisador aborda a questão do aceleramento gerado pela mídia terciária, o que zera o espaço, pois é possível, por exemplo, conversar com uma pessoa que está do outro lado do mundo via aplicativo na internet, dando uma sensação de proximidade.

A questão do script como imagem

$\mathrm{O}$ meio de o operador interagir com o público, principalmente o operador do call center ativo - que toma a iniciativa de contatar o cliente -, é o script, traduzido para o português, o roteiro. Segundo Algodoal, "script é um roteiro destinado à leitura dos operadores de telemarketing em diversas empresas" (2002, p. 26).

Lima o define como um roteiro definido previamente pelos gestores das centrais de atendimento. Tem como objetivos nortear, orientar e auxiliar o diálogo que o operador irá estabelecer com o cliente. No entanto, afirma Lima, ao se observar as condições de trabalho e os perfis dos profissionais selecionados para atuar como operadores, nota-se uma outra função: controlar o tempo de atendimento e até mesmo controlar a comunicação feita nas ligações (2007, p. 109).

A estratégia das empresas em tentar estabelecer o script como um facilitador do serviço, seja visando à aceleração do atendimento ou à facilitação do trabalho do operador, principalmente dos mais 
inexperientes, é uma tentativa radical de reduzir o processo da comunicação, de forma a comprometê-la.

De acordo com Baitello Junior, a comunicação se faz por meio de pontes, e os comunicadores são aquelas pessoas que constroem a ponte até o outro, e assim estabelecem alteridades, com uma única manobra: colocando-se no lugar do outro, sem perder a própria referência. Sendo assim, para o autor, estar conectado não significa estar se comunicando. A conexão seria a ponte vazia que os comunicadores só atravessariam se se colocassem no lugar do outro, bem como se deixassem o outro se colocar em seu lugar (BAITELLO JUNIOR, 2011, s/p).

O professor e pesquisador Paulo Barroso, da Universidade de Algarve, em Portugal, afirma que existe um paradoxo na comunicação, o de exprimir o inexprimível. Afinal, a comunicação exprime uma experiência - pensamentos, sensações e percepções -, mas a experiência faz parte do universo particular de cada um, é subjetiva, enquanto a comunicação é regular e lógica. Dessa forma, a deslocação semântica, segundo o autor, acontece em dois níveis: da linguagem da mente para a linguagem verbal (interno) e da linguagem verbal do emissor para o receptor (externo). Se há uma comunicação regular, que produz interação, há também, segundo Barroso, uma comunicação patológica ou agramática, geradora de desvios entre os interlocutores. Ora, no caso do operador de call center, seu papel de interlocutor se torna ainda mais complexo, uma vez que tenta exprimir o inexprimível (a experiência) ao mesmo tempo em que deve exprimir o que está impresso (script).

Há, portanto, uma patologia na linguagem adotada pela empresa de call center, pois é pautada por um roteiro préconcebido. Ao atendente é permitido exprimir pouco de sua experiência, deve-se seguir o script; sua expressão fica comprometida, gerando angústia e a sensação de que a troca comunicativa não foi realizada de forma plena. Para o consumidor, a patologia da linguagem fica evidente quando ele pergunta alguma coisa e obtém uma resposta sem sentido, distante do que foi perguntado.

Dessa maneira, o que deveria facilitar, muitas vezes acaba por tolher o trabalho dos operadores, segundo depoimento deles mesmos em alguns estudos analisados. De fato, a pesquisa de Lima, que colheu depoimentos dos operadores acerca do uso do script, não constatou seu papel facilitador em todas as situações. Pelo contrário, mostrou o descontentamento desses trabalhadores ao serem obrigados a utilizá-lo. Um dos entrevistados afirmou que o roteiro é "repetitivo demais" e "cansativo" (2007, p. 119); outra pessoa relata que o script é uma barreira para a naturalidade da conversa com o cliente (2007, p. 95); um operador fala do caráter do script de tornar o humano robotizado e afirma que, se fosse dada liberdade para ele falar como quiser, depois de tanto tempo usando o script, ele acredita que não saberia o que falar (2007, p. 119). Venco também detecta a preferência dos trabalhadores por usar o script de forma livre, como um norteador do trabalho e não de forma rígida (2006, p. 184).

Pode-se afirmar que o método utilizado pelos call centers para se conectarem aos seus consumidores é muito mais discursivo do que dialógico, principalmente pelo fato de se impor um script para ser seguido durante a conversa. Segundo Flusser, o diálogo se dá pela troca de informações disponíveis a fim de se obter uma nova informação, enquanto o discurso ocorre para preservar e manter uma informação existente, para que as informações compartilhadas resistam ao efeito entrópico da natureza (2007, p. 96-97).

Algodoal afirma ser o script um mecanismo de controle, que é usado em maior ou menor intensidade, a depender do 
perfil da empresa (2002, p. 25). Lima chama a atenção para o fato de que eles são obrigados a usá-lo de forma rigorosa independentemente da resposta do cliente (2007, p. 112). No caso citado, pode-se perceber a patologia da comunicação, conforme enunciou Barroso. Existe um esforço por parte dos operadores de criar táticas para burlar a obrigatoriedade do roteiro, segundo Lima, "buscando outras formas de comunicação que não sejam somente a verbal, como por exemplo, entonação de vOz, ritmo de fala, bem como repetição de palavras (...).” (2007, p. 112).

O script, neste contexto, pode ser considerado uma imagem reproduzida em série. Flusser já havia afirmado que a "escrita é meta-código da imagem" (1985, p.16). Uma imagem de diálogo que já não existe e não quer existir, cuja função de imagem se mantém por meio da insistência da empresa em utilizá-lo, desconsiderando que, de um lado e de outro, existem dois corpos, duas pessoas que se comunicam com toda a complexidade inerente à mídia primária.

Uma imagem, segundo Baitello Junior, é a presença de uma ausência e também seu oposto, ou seja, a ausência de uma presença. As imagens não são produtos da luz, mas sim seres da noite, o que significa que possuem muito mais faces invisíveis do que visíveis. Mas imagens não se configuram apenas naquilo que se vê; sua linguagem pode variar e, assim, serem imagens acústicas, olfativas, táteis. Elas têm vontade própria, e seduzem quem tiver em seu entorno (2005, p. 45-46). Assim, encontra-se a sociedade na seguinte configuração:

A nova sociedade não mais vive de pessoas, feitas de corpos e vínculos, ela se sustenta sobre os pilares de uma infinita 'serial imagery', uma sequência infindável de imagens, sempre idênticas. $O$ admirável e desejável já não é mais a diferença, mas a absoluta semelhança. Não mais a capacidade criativa e adaptativa é o que se sobressai, mas sim a necessidade de pertencimento (2005, p.51).

Baitello Junior desenvolve o conceito de sociedade entômica2, na qual os homens passaram a viver como os insetos, ou seja, tendo de sincronizar grandes massas, vivendo em comunidades de milhões, entomizando tempo e espaço. Assim, o indivíduo cede lugar a um homem que é parte completa do todo, e por isso, seu funcionamento está atrelado ao todo, para que $\mathrm{O}$ todo funcione. $\mathrm{O}$ homem nesse contexto é um homem dividido. A sociedade entômica é capaz de reduzir a complexidade do indivíduo, e também de dividir e especializar o trabalho, proporcionando a "repetição exaustiva de gestos, de movimentos, de padrões, de atitudes, de modelos, de ideias" (BAITELLO JUNIOR, 2005, p.52). Essa sociedade se expande por meio da construção e da cópia de imagens, o que dá margem ao surgimento de outra sociedade paralela, a imagética, que vem tentar oferecer imagens de individualidade, realização, futuros, projetos, oferecendo as múltiplas dimensões perdidas, reproduzindo imagens de forma desenfreada (2005, p. 52)

De acordo com Baitello Junior, a reprodutibilidade hodierna, fruto da tecnologia, segue a lógica do eco. A sociedade vive sem memória profunda, repetindo sons finais, repetindo superfícies, vivenciando apenas o eco das superfícies. Trata-se de uma sociedade desmemoriada, guiada pelo que o autor chama de princípio da Eco-Logia (estudo dos efeitos das imagens em eco), que substitui a Ecologia, ou seja, o estudo do meio ambiente, o que inclui o ambiente comunicacional (2005, p. 52-53).

2 Segundo o autor, "entomon", em grego, significa dividido, partido. 
Ora, o script pode ser considerado um viés do princípio do eco. Sem a memória da comunicação complexa, é condenado a se repetir, sempre, sem a intenção da comunicação de fato, mas $\operatorname{sim}$ da reprodutibilidade constante. Trata-se da presença de uma ausência, da simulação de um diálogo entre empresa e seu público, da ausência de uma comunicação que poderia ocorrer entre duas pessoas conectadas.

\section{A loucura no trabalho}

Segundo pesquisadores que analisaram o ambiente do trabalho em call center, trata-se de um ambiente de sofrimento, causador de doenças físicas e psicológicas. Ao mesmo tempo, os trabalhadores conseguem extrair consequências positivas da atividade, como $o$ fato de conquistar novos amigos e melhorar a forma de se expressar. Eles estão criando um universo novo, necessário para 'solucionar' a negatividade do ambiente em que passam boa parte dos seus dias.

Essa ação pode ser analisada por meio dos conceitos do estudioso da Semiótica da Cultura Ivan Bystrina. Segundo ele, existem três códigos culturais, que formam um conjunto de leis que normalizam a cultura. Para Bystrina, a cultura é auto-referente, ou seja, em seu cerne pulsante e dinâmico ela existe como cultura pela cultura3. Os códigos primários regulam a vida biológica; os secundários, que são os códigos da linguagem, dizem respeito à sociedade; e os terciários se referem à cultura, à junção da primeira e da segunda realidade. A primeira realidade é o universo físico, enquanto a segunda realidade é o mundo imaginário, para ele garantidor não só da sobrevivência física e material do homem, mas principalmente da sua sobrevivência psíquica (1995, p. 4).

A estrutura básica dos códigos terciários é formada pela binariedade,

3 Explicação dada em sala de aula pelo professor Norval Baitello Junior, na disciplina Teoria Semiótica - Semiótica da Cultura, no dia 18 de agosto de 2011.

Augusto Guzzo Revista Acadêmica, 2014, N 13 observada no mundo físico, cuja oposição mais importante é vida-morte, além de saúde-doença, homem-mulher, paz-guerra, entre outras. Também é formada pela polaridade, em que cada polo recebe um valor, a exemplo da vida e da morte, cuja tendência é a preservação da primeira. Dessa forma, existe uma assimetria na estrutura binária e polar, explicada justamente pelo exemplo vida-morte, pois o polo negativo é percebido sempre como o mais forte: a morte sempre parece ser mais forte do que a vida. $\mathrm{O}$ homem busca suprimir essa polaridade por meio de soluções simbólicas, entre elas a inversão da polaridade (1995, p. 7).

É o que foi observado em alguns ambientes de trabalho em call center. A pesquisa de Scolari identificou alguns fatores que geram sofrimento, e também apurou os fatores geradores de prazer, a saber: as relações interpessoais, o estabelecimento de amizades e o contato com pessoas, que têm relação com o estabelecimento de vínculos; e os benefícios do trabalho, como a possibilidade de ser contratado mesmo sem experiência anterior no segmento, a possibilidade de ampliação do salário com o tempo de permanência e o vínculo empregatício (2007, p. 124-126). Isso evidencia que os trabalhadores conseguem extrair boas experiências mesmo diante de uma atividade penosa. Pode-se considerar esse fato como a busca da solução simbólica de inverter a realidade negativa e conseguir chegar ao seu polo positivo, uma das estratégias usadas para amenizar a rotina de trabalho no call center.

Nos estudos de Christophe Dejours sobre psicopatologia do trabalho, há o enfoque da contaminação do tempo fora desta atividade. "Despersonalizado no trabalho, ele permanecerá despersonalizado em sua casa" (1988, p. 46), afirma o pesquisador, que acredita ser muito difícil se dissociar o tempo no trabalho e fora dele. Nas folgas, muitas vezes os trabalhadores cronometram suas horas de atividade e repouso, 
conservando a preocupação com o tempo, a vigilância permanente. Para Dejours:

Assim, o ritmo do tempo fora do trabalho não é somente uma contaminação, mas antes uma estratégia, destinada a manter eficazmente a repressão dos comportamentos espontâneos que marcariam uma brecha no condicionamento produtivo (1988, p.47).

Por louco, pode ser considerado aquele que perdeu o senso de realidade. Iasbeck cita Bystrina para definir a loucura sob a ótica da Semiótica da Cultura: o louco é aquele que perdeu a noção de diferenciação entre a primeira e a segunda realidade. Isso significa que a loucura não afasta a pessoa da realidade (dimensão biológica e social), mas a aproxima intensamente $\mathrm{da}$ segunda realidade, $\mathrm{da}$ dimensão psicológica fortemente marcada pelos símbolos e associações (2005, p. 36).

De fato, Bystrina coloca as variantes psicopatológicas como uma das quatro raízes da cultura. Junto com elas, as outras três raízes são o sonho, o jogo e as atividades lúdicas e os estados alterados de consciência, ou seja, as situações de êxtase e euforia. "O mundo das variantes psicopatológicas oferece um poderoso exemplo de desprendimento das regras de codificação e decodificação dos mais diversos aspectos da vida biofísica e social" (BAITELLO JUNIOR, 1997, p. 21).

E porque o trabalho pode ser um ambiente propiciador da loucura? Souza (2005) analisa o ambiente corporativo como uma arena de representações simbólicas balizadas pela cultura, por mitos e crenças. $\mathrm{E}$, nesse ambiente, é a empresa que estabelece para seus funcionários quais papéis serão representados e como serão. Os funcionários, reféns da situação e com objetivos de realização pessoal, podem entrar em conflito ao tentar desempenhar os papéis dados. Sendo assim, em situações limítrofes correrão o risco de apresentarem diversos tipos de psicopatologia conforme a autora (2005, p. 11-12).

Dejours estuda o medo, sentimento presente no trabalho. Em indústrias nas quais os perigos realmente existem, como construção civil, setor químico, entre outras, os trabalhadores também manifestam a ideologia defensiva, desta vez no sentido de negarem e desprezarem os riscos ao seu redor. Eles chegam a desafiar o perigo, em performances pessoais, pois, segundo Dejours, "criar uma situação ou agravá-la é, de certo modo, dominá-la" (1988, p. 70). É um sistema defensivo para controlar o medo, e sua eficácia depende do engajamento de todos, deve ser um comportamento coletivo. Mais uma vez há busca por uma solução simbólica para aplacar esse sentimento, uma inversão do medo por meio da coragem do grupo em se defrontar com situações que o deflagram.

A ansiedade gerada pelo medo também é observada pelo autor em trabalhos que exigem ritmos de produção e velocidade, o que leva ao esgotamento progressivo do trabalhador. Porém, neste caso, não cabem defesas coletivas, cada profissional deverá administrar sua própria ansiedade. O call center é um terreno propiciador dos sentimentos de medo $\mathrm{e}$ ansiedade, que podem levar o trabalhador a casos mais graves de psicopatias, como neuroses, psicoses e depressões. Mantendo os trabalhadores num estado de permanente atenção, desta forma o medo é utilizado pelos administradores das empresas como uma alavanca para fazer trabalhar (1988, p. 112).

As neuroses e psicoses, de acordo com Dejours, podem ser identificadas pela queda de desempenho produtivo do trabalhador (1988, p. 120) e dependem da estrutura das personalidades. Alguns fatores da relação homem-organização de trabalho 
podem desencadear a descompensação4: a fadiga; o sistema frustração-agressividade reativa; e a organização do trabalho. Há, ainda, a doença somática, que aparece em pessoas cujas defesas mentais são ineficazes e quando não há a descompensação de um modo neurótico ou psicótico. Defesas de caráter ou de comportamento, quando são neutralizadas, acabam por produzir a doença somática, pois pessoas com essa característica ficam mais frágeis diante de situações adversas da vida. E é mais uma vez a intensidade da rigidez da organização do trabalho que afetará o indivíduo a tal ponto que o faça desenvolver uma doença psicossomática.

\section{A vigilância intimidadora}

No trabalho de call center, a ação de vigilância é permanente. A figura do supervisor, cujo nome do cargo já indica alguém que vê de forma ampla, está o tempo todo com os operadores. De acordo com pesquisa de Scolari, o controle exercido pelas gravações telefônicas gera ansiedade nos trabalhadores e faz com que eles se sintam mais dependentes do script ao conversar com o público. Eles se sentem ameaçados, pois podem ser punidos caso se comportem fora do previsto (2007, p. 48). Afinal, como afirma Foucault, "o corpo só se torna útil se é ao mesmo tempo corpo produtivo e corpo submisso" (2010, p. 29).

Venco explica que a monitoração dos atendimentos é sistemática e permite ao supervisor dar ao funcionário o feedback, ou seja, orientações a respeito de como ele deve proceder em sua tarefa. Apesar de também ser um fator positivo, no sentido de ser a ferramenta para que o trabalhador melhore seu atendimento, ainda sim é gerador de tensão para quem está sendo monitorado. Além da utilização para melhoria do atendimento, Venco afirma que a gravação também é utilizada como "arma" para ameaças de demissão por justa causa. Segundo entrevistas feitas pela pesquisadora,

4 Termo usado pelo autor.

Augusto Guzzo Revista Acadêmica, 2014, N 13 os supervisores podem valer-se de advertência verbal e escrita, além da própria demissão, caso encontrem nas gravações alguma fala que não segue os procedimentos do atendimento (2006, p. 77).

O estado permanente de controle é, para Dejours, um meio muito eficaz, pois se trata de uma "construção artificial de autocontrole" (1988, p. 101). As pessoas, por medo da vigilância, passam elas próprias a se vigiarem permanentemente. A disciplina, nesse sentido, é técnica específica de poder, e faz dos trabalhadores os instrumentos para sua execução e os torna objetos. E, para usufruir desse poder, bastam simples medidas como o olhar hierárquico, a sanção normalizadora e o exame (FOUCAULT, 2010, p. 164).

O sofrimento dos trabalhadores pode ser vantajoso para as empresas, afinal, se o sofrimento pode ser traduzido, por exemplo, por aumento da ansiedade, as pessoas podem acelerar o trabalho e, assim, tornarem-se mais produtivas. Dessa forma, esse sentimento é explorado, e não por si só, mas pelas consequências que suscita. É o caso relatado por Dejours, que aborda a exploração do sofrimento de telefonistas. Relatado por elas como um trabalho que as tornam "idiotas", com mensagens falsas, que as impede de serem amáveis com as pessoas, é um trabalho que as deixam nervosas. E, quanto mais esse estado se intensifica, também a auto-repressão aumenta, transformando a telefonista "na artesã de seu próprio condicionamento" (1988, p. 102). E, assim, a única saída para a agressividade é fazer sua tarefa com mais rapidez.

Apesar do sofrimento, os operadores conseguem superar as adversidades por meio de estratégias de resistência. Ora, por mais restrições e disciplinas a que esses corpos estejam submetidos, ainda sim são corpos e precisam criar a vinculação com o outro. São corpos que estão ali não somente para cumprir a rotina da comunicação (ou conexão) no âmbito da mídia terciária. Se a comunicação começa no corpo e termina no 
corpo, como afirma Pross, é esse fenômeno que vai emergir mesmo com todas as proibições.

Uma das resistências observadas se relaciona com o script, que muitas vezes não é seguido à risca. A ele é somada a emoção do operador, deflagrada pela sua voz, que desvia do caráter neutro que a empresa objetiva aplicar às ligações. Outra atitude de resistência é fazer amizades, o que aumenta a identificação entre as pessoas, uma vez que elas compartilham de muitas características comuns (SCOLARI, 2007, p. 73). Os operadores, por meio do diálogo, trocam ideias e assim percebem que sofrem com os mesmos problemas.

Alguns relatam que burlam a regra de proibição de comida no ponto de atendimento e comem nesse local. Segundo Venco, os jovens trabalhadores buscam formas criativas para se descontraírem, como aprender Libras, a língua brasileira de sinais, para conseguir estabelecer uma comunicação entre o grupo.

São com medidas simples e criativas que os operadores conseguem ultrapassar as fronteiras das proibições e pressões do trabalho, mostrando que, onde há um corpo, há resistência quando se tenta aplicar a esse corpo ritmos e pressões abusivas. Afinal, como afirma Baitello Junior, o corpo é linguagem e produtor de linguagens, e dessa maneira é que se aproxima e se vincula a outros seres humanos, estabelecendo relações e parcerias (2005, p. 62).

O corpo e o pensamento sentados

A ação de sentar é uma tentativa de domar o corpo e civilizar o homem, e tornou-se símbolo de conforto. A tecnologia estimula ainda mais essa ação, já que seus aparelhos foram feitos para serem operados por uma pessoa sentada. No universo do trabalho, são muitas as profissões que exigem a acomodação do homem numa cadeira para executar suas tarefas (BAITELLO JUNIOR, 2012, p. 18).

$\mathrm{O}$ ato de sentar tem muita afinidade com as tecnologias utilizadas nos dias atuais. Baitello Junior lembra que até mesmo as máquinas que transportam pessoas as fazem sentar. Sentar traz dois efeitos opostos: tensão e relaxamento, ao mesmo tempo (2012, p. 35). Os músculos ficam tensos, como um operador de call center relatou em pesquisa citada anteriormente; mas, ao se levar em conta a dinâmica dos jogos eletrônicos, que na maioria das vezes são jogados na posição sentada, é também um momento de relaxamento.

É sentado que o homem pode, também, viajar sem sair do local em que se encontra. Baitello Junior chama o fenômeno de neonomadismo, e explica:

Somos neonômades que deixamos o corpo no depósito de corpos, as cadeiras, e viajamos ilimitada e irrestritamente, pagando apenas as conexões, em processo de barateamento, os pulsos telefônicos, igualmente cada vez menos caros, e máquinas imbatíveis (também cada dia menos raras e menos caras, mais familiares e onipresentes) (2012, p. 45-46).

Quando se está sentado, o corpo está dobrado em duas partes: nos joelhos e no quadril. Nessa posição, perde-se a herança de duas raízes que constituem o homem, a inteligência primata (saltitante) e a inteligência nômade (caminhante). E, para manter o homem na posição de assentamento, sedado e seduzido, são oferecidas imagens provenientes das máquinas, ou melhor, das telas das máquinas (2012, p. 69). Sentados, os homens não conseguem atuar de forma transformadora no mundo (2005, p. 37). 
Incomunicação nos pontos de atendimento

O objeto analisado por esse estudo é eminentemente prático. Trata-se de um fenômeno de conexão, que emerge na prática da conversa telefônica entre $\mathrm{O}$ operador de call center e o consumidor. Estabelece-se uma conexão, mas ela gera uma comunicação? Se há um discurso pronto a ser pronunciado, Flusser já deu pistas de que o diálogo é preterido. Portanto, pode-se considerar que, nessa prática, o que existe, resguardando as exceções, é a incomunicação, contextualizada da seguinte maneira por Baitello Junior:

Quanto mais se aperfeiçoam os recursos, as técnicas e as possibilidades que o homem tem de se comunicar com o mundo, com os outros homens e consigo mesmo, aumentam também, em idêntica proporção, as suas incapacidades, suas lacunas, seu boicote, seus entraves ao mesmo processo, ampliando um território tão antigo quanto esquecido, o território da incomunicação humana. Assim, andam de mãos dadas e crescem juntas, como irmãs gêmeas, a comunicação e a incomunicação (2005, p.9).

De acordo com ele, é por meio dos excessos que a incomunicação se manifesta, inclusive no excesso de ordem e de tempo. E esses dois excessos são observados no call center. $O$ de ordem, quando se aplica exageradamente a disciplina, por meio da vigilância e pela obrigatoriedade do seguimento de um script pré-determinado. $\mathrm{E}$ o excesso de tempo, no qual a aceleração dita as regras, impondo aos trabalhadores que façam o maior número de ligações, e que elas durem o menor tempo possível.

Um ambiente estressante, exaustivo e redundante possibilita a incomunicação, que está ligada também a algumas formas leves de loucura (IASBECK, 2005, p.35). Mas vale lembrar que é impossível não se comunicar (WATZLAWICK apud

Augusto Guzzo Revista Acadêmica, 2014, N 13
IASBECK, 2005, p.36), então a incomunicação acaba por proporcionar outras formas de comunicação. No caso estudado, por exemplo, a comunicação da entonação da vOz, o movimento do corpo e as roupas que são vestidas. Até mesmo o silêncio comunica (LIMA, 2007, p.99). Aquilo que a empresa se propôs comunicar, ou seja, a resolução de problemas ou o esclarecimento de dúvidas do consumidor, pode não acontecer, mas em consequência dela outras comunicações ocorrem, como por exemplo, um tom de voz que indica certa irritação ou a própria transgressão do operador em não seguir o script, deixando a conversa acontecer de forma mais espontânea.

De fato, segundo Silva, não é possível definir incomunicação como tudo aquilo que não é comunicação. Afinal, comunicação e incomunicação dividem o mesmo espaço, ao mesmo tempo. Aliás, a questão do espaço tem papel fundamental na comunicação; a ausência desse espaço comum5, fruto da evolução tecnológica, pode esvaziar as relações de pertencimento e as criações de vínculos (2005, p. 65). Essa é a diferença entre a mídia primária e a terciária. E, com isso, abre caminho para a incomunicação. "Transformamo-nos numa sociedade conectada mas não vinculada" (2005, p. 65). Por vinculação entende-se a relação que permite trocas simbólicas; por conexão, é a troca rápida destinada a saciar desejos, entre eles, o desejo por informação. Daí a importância de se diferenciar a comunicação da conexão (transmissão).

A incomunicação proveniente da organização de trabalho no call center pode propiciar algumas situações confusas para os operadores. A pesquisa de Lima verificou que esses profissionais, muitas vezes, não sabem como agir no atendimento. A dificuldade provém das mudanças constantes do tema das ligações, a diferença entre o telemarketing ativo para o passivo (algumas empresas usam os operadores para

5 Para Baitello Junior, o espaço comum se constrói a partir da somatória dos espaços individuais (2005, p. 77). 
ambas modalidades), e, principalmente, a dificuldade em se comunicar com os superiores (2007, p.108).

Algumas empresas de call center já perceberam que o uso rígido do script, por exemplo, era um obstáculo para a comunicação, e não um agregador. Por isso, pelo menos no telemarketing ativo, que trabalha com vendas, o uso do script se tornou mais flexível. $\mathrm{O}$ resultado da flexibilidade foi o aumento nas vendas, pois o operador pode interagir mais com $\mathrm{O}$ consumidor "estabelecendo um contato original, e não um atendimento robotizado" (VENCO, 2006, p. 172). Para os operadores, é um consenso a preferência pelo uso livre do script, que pode ajudar como um orientador do trabalho e não como um texto a ser seguido com rigor (2006, p. 174).

Existem muitas contradições nesse trabalho, em que o operador precisa ser simpático, mas não demonstrar emoções; deve ser atencioso, mas também evitar a aproximação do outro; e tem de desenvolver uma relação de confiança sem se valer de uma comunicação autêntica6. A conversa é real, porém o operador se comporta como um ator que recita um texto e tem de demonstrar imagem do conhecimento que não detém (SILVA et al. apud SCOLARI, 2007, p. 40).

Essa repressão no comportamento e na linguagem torna as ligações em call center uma prática esvaziada de seu sentido. Tratase de uma espécie de encenação do atendimento ao cliente, com direito a um script, o script-imagem, para que os "atores" desse teatro interpretem robôs designados a emitir o que está escrito no roteiro, sem

6 Para Zarifian, comunicação autêntica na atividade profissional é um processo que inclui a compreensão recíproca e a formação de um sentido compartilhado. Isso resulta num entendimento a respeito das ações que as pessoas envolvidas assumem, seja juntas ou convergentemente (2001, p. 165). ações ou reações emocionais tipicamente humanas. Baitello Junior já afirmou que, quando as imagens passam a ditar a comunicação, elas são os "atravessadores" entre o homem e o mundo. Para que isso ocorra, os meios, a mediação é amplificada, para atingir as massas $(2005$, p. 28$)$.

A questão das limitações nos atos de linguagem no call center é encarada por Zarifian como uma verdadeira taylorização da linguagem. Para ele, padronizar a pronúncia de palavras, ritualizar a linguagem para o cliente, como no caso da polidez das frases e da estratégia de desconstrução dos argumentos do cliente (relacionados à sua insatisfação), restringir o tempo de fala e usar a escuta (feita pela hierarquia) para controlar as respostas, são indícios da taylorização nos atos de linguagem. Para ele, a consequência imediata dessas estratégias é a perda da capacidade de dominar a própria linguagem, sem poder, ao menos, recorrer ao silêncio, já que a atividade não permite isso.

A criação de vínculos para o estabelecimento de uma comunicação é impedida de diversas formas. Segundo Lima, a empresa de call center, além de padronizar a fala por meio do script, também dita a entonação da vOz, para que não fiquem evidentes manifestações emocionais. É uma tentativa, assim como já afirmou Zarifian, de usar a linguagem como uma simples ferramenta de trabalho. O operador deve ser gentil, porém não deve prolongar seu discurso nem expressar suas emoções (LIMA, p. 124). Isso descarta qualquer possibilidade de criação de vínculos e despreza a complexidade da comunicação já que, conforme assegura Cyrulnik, "qualquer conversação, ainda que banal, exige a percepção e a decodificação de um número incalculável de sinais para se compreender seu significado" (1995, p. 23).

Ainda assim, as empresas utilizam o atendimento ao consumidor via call center a fim conquistar mais clientes, vender e 
"fidelizar" clientes antigos (LIMA, 2007, p. 118). Ora, todas essas palavras, usadas amplamente no ambiente corporativo, dizem respeito à criação de vínculos. Como conquistar, seduzir, sem estar vinculado ao outro? Mais difícil ainda é a arte da negociação, por meio da qual se busca conseguir vender um produto ou serviço que muitas vezes o ouvinte do outro lado da linha nem precisa. Como negociar sem se vincular? Por fim, a intenção de "fidelizar" o cliente, que significa fazer com que ele sempre adquira determinado produto ou permaneça renovando o contrato com a empresa, supõe-se que isso só aconteceria mediante uma relação de confiança e satisfação, construída com o tempo. E uma construção de relacionamento requer também construção de vínculos, o que a maioria das empresas de call center não tem a preocupação em criar ou estimular.

\section{Referências bibliográficas}

ALGODOAL, Maria Juliana Amatuzzi de Oliveira. As práticas de linguagem em situação de trabalho de operadores de telemarketing ativo de uma editora. 2002. Tese (Doutorado em Linguística Aplicada e Estudos da Linguagem) - Faculdade de Filosofia, Comunicação, Letras e Artes - Pontifícia Universidade Católica de São Paulo, São Paulo, 2002.

BAITELLO JUNIOR, Norval. O pensamento sentado. Sobre glúteos, cadeiras e imagens. São Leopoldo, RS: Editora Unisinos, 2012.

cultura do ouvir". In: Centro Interdisciplinar de Semiótica da Cultura e da Mídia. Disponível em: <www.cisc.org.br>. Acesso em 10 de novembro de 2011.

BARRETO, José Roberto. "A comunicação e os ritos do calendário". Entrevista com
Harry Pross. In: Centro Interdisciplinar de Semiótica da Cultura e da Mídia. Disponível em: <www.cisc.org.br>. Acesso em 13 de setembro de 2011.

"Comunicação Afetiva". In: Revista E - Sesc, $\mathrm{n}^{\circ}$ 168, maio de 2011. Disponível em: $<$ http://sescsp.org.br/sesc/revistas/revistas _link.cfm?Edicao_Id=403\&Artigo_ID=614 $3 \&$ IDCategoria $=7079 \&$ reftype $=2>$. Acesso em 17 de fevereiro de 2013.

A

Era da iconofagia: ensaios de comunicação e cultura. São Paulo: Hacker Editores, 2005.

CONTRERA, Malena Segura; e MENEZES, José Eugênio de O. Os meios da Incomunicação. São Paulo: Annablume, 2005.

"Vilém Flusser e a Terceira Catástrofe do Homem ou as Dores do Espaço, a Fotografia e o Vento". In: KONDO, Kojin; SUGA, Kejiro (orgs). How to talk to photography. Tokyo: Kokushokankokai, 2005, p. 87 a 94.

$$
\text { "As }
$$

núpcias entre o nada e a máquina". In: BERNARDO, Gustavo (organização). Literatura e Ceticismo. São Paulo: Annablume, 2005, p. 25-41.

tempo lento e o espaço nulo. Mídia primária, secundária e terciária". In: NETO, Antônio Fausto; HOHFELDT, Antônio; PRADO, José Luiz Aidar e PORTO, Sérgio Dayrell (Orgs.). Interação e sentidos no ciberespaço e na sociedade. Compós, volume 2. Porto Alegre, EDIPUCRS, 2001b.

BARROSO, Paulo. Linguagem entre Experiência da Comunicação e Comunicação da Experiência. Disponível 
em <http://bocc.ubi.pt>. Acesso em $1^{\circ}$ de maio de 2013.

BRASIL, Ministério do Trabalho e Emprego, Secretaria de Inspeção do Trabalho, Departamento de Segurança e Saúde no Trabalho. Segurança e Saúde nas Atividades de Teleatendimento. Recomendação Técnica DSST No 01/2005, 15p., março de 2005.

BYSTRINA, Ivan. Distanciamento e Envolvimento - uma Oposição. In: Revista de Comunicação, Cultura e Teoria da Mídia (Ghrebh). Disponível em: www.cisc.org.br. Acesso em 18 de novembro de 2011.

Tópicos de Semiótica da Cultura. (Pré Print). São Paulo: CISC, 1995.

CYRULNIK, Boris. Os Alimentos do Afeto. São Paulo: Editora Ática, 1995.

DEJOURS, Christophe. A loucura do trabalho. São Paulo: Cortez Editora, 1988.

FLUSSER, Vilém. Filosofia da Caixa Preta. Ensaios para uma futura filosofia da fotografia. São Paulo: Hucitec, 1985.

. Pós-história.Vinte instantâneos e um modo de usar. São Paulo: Duas cidades, 1983.

FOUCAULT, Michel. Vigiar e Punir. Petrópolis, RJ: Vozes, 2010.

IASBECK, L. C. A. "A Incomunicação da Loucura". In: BAITELLO JUNIOR, N., CONTRERA, M. S., MENEZES, J. E. de O., Os meios da Incomunicação. São Paulo: Annablume, 2005.

KAMPER, Dietmar. "Re-signição em São Paulo". In: Centro Interdisciplinar de Semiótica da Cultura e da Mídia. Disponível em: <www.cisc.org.br>. Acesso em 08 de setembro de 2011.

"Estrutura temporal das imagens". In: Revista de Comunicação, Cultura e Teoria da Mídia (Ghrebh), outubro de 2002, $\mathrm{n}^{\circ} 01$. Disponível em: <www.cisc.org.br>. Acesso em 08 de julho de 2011.

como vida. São Paulo: Annablume, 1998.

LIMA, Elisabeth de. As condições de trabalho e as estratégias de comunicação nas operações de call center. 2007. Dissertação (Mestrado em Administração) Faculdade de Economia, Administração, Contábeis e Atuariais - Pontifícia Universidade Católica de São Paulo, São Paulo, 2007.

MANCINI, Lucas. Call Center: Estratégia para vencer. São Paulo: Summus, 2006.

OLIVEIRA JÚNIOR, M.M. (coord.). Relatório da indústria de call centers no Brasil 2005. Programa de PósGraduação em Administração, PUC-SP e ABT, 2005.

$$
\text { PROSS, Harry. "Aceleração e }
$$
Perda". In: Centro Interdisciplinar de Semiótica da Cultura e da Mídia. Disponível em: <www.cisc.org.br>. Acesso em 08 de julho de 2011.

"A Economia dos Sinais e a Economia Política". In: Centro Interdisciplinar de Semiótica da Cultura e da Mídia. Disponível em: <www.cisc.org.br>. Acesso em 08 de julho de 2011.

Estructura simbólica del poder. Barcelona: Editorial Gustavo Gili, 1980. 
SCOLARI, Carolina Casagrande. Prazer e sofrimento entre os trabalhadores de call center: um estudo descritivo em uma empresa no Rio Grande do Sul. 2007. Dissertação (Mestrado em Administração) Escola de Administração - Universidade Federal do Rio Grande do Sul, Porto Alegre, RS, 2007.

SILVA, Airton Marinho da. A Regulamentação das Condições de Trabalho no Setor de Teleatendimento no Brasil: necessidades e desafios. 2004. Dissertação (Mestrado em Saúde Pública) - Faculdade de Medicina, Universidade Federal de Minas Gerais, Belo Horizonte, MG, 2004.

SILVA, Maria de Fátima da. As práticas de Recursos Humanos e o resultado operacional do call center. 2007. Dissertação (Mestrado em Administração) - Faculdade de Economia, Administração, Contábeis e Atuariais - Pontifícia Universidade Católica de São Paulo, São Paulo, 2007.

SILVA, Maurício Ribeiro da. "Os Caminhos da Incomunicação". In: BAITELLO JUNIOR, Norval; CONTRERA, Malena Segura; e MENEZES, José Eugênio de O. Os meios da Incomunicação. São Paulo: Annablume, 2005, p.59-70.

SOUZA, Mônica Maria Martins de. Comunicação interna na empresa e loucura corporativa: um estudo de caso. Tese de doutorado. São Paulo, PUC, 2005.

VASCONCELOS, Ana Paula Gomes. Call centers e incomunicação. Estudo sobre a aceleração do trabalho e padronização do diálogo entre operador e cliente. Dissertação (Mestrado em Comunicação e Semiótica). Pontifícia Universidade Católica de São Paulo, São Paulo, SP, 2013.

VENCO, Selma Borghi. Tempos moderníssimos nas engrenagens do telemarketing. 2006. Tese (Doutorado em Educação) - Faculdade de Educação Universidade Estadual de Campinas, Campinas, SP, 2006.

ZARIFIAN, Philippe. "Comunicação e Subjetividade nas Organizações". In: Davel, E. Vergara, S.C. (organizadores). Gestão com Pessoas e Subjetividade. São Paulo: Atlas, 2001, p. 149-170. 